\title{
LIEUTENANT GRAVES AT LA BOURSE
}

Face flat to the mud-earth, a soldier

sleeps. But no. You see,

clear as a flare

in darkness, a block

of saturated beige:

his moist foot, bare against the ground. This man

from Limerick

removed his boot

to pull-a corporal, smoking,

tells you-the trigger

with his toe. The barrel, he says, was just

a cigar in his mouth. Tomorrow,

billeted in La Bourse, the monsieur's daughter

lifts her gray skirt, unwashed

for weeks. You turn your eyes

to the field of poppies, silver

in the full moon.

She insists. She holds

the raised pleat with small hands

that remind you of soft dough.

There is a long gash, purple,

across her smooth thigh.

She bends to let the cotton fall

to her ankles. You begin to walk-

The Germans, their shells,

you say. They cut down the poplars

like rows of spring tulips. 